\title{
Mineralogy and Fluid Inclusion Microthermometry of Epithermal Gold-Base Metal Mineralization at Anggai, Obi Island, Indonesia
}

\author{
Irzal Nur*, Ulva Ria Irfan*, Alwi La Masinu ${ }^{+}$ \\ ${ }^{\#}$ Mining Engineering Department, Hasanuddin University, Jl. Poros Malino KM.6, Gowa, 92171, Indonesia \\ E-mail:irzal.nur@eng.unhas.ac.id \\ *Geological Engineering Department, Hasanuddin University, Jl. Poros Malino KM.6, Gowa, 92171, Indonesia \\ E-mail: ulvairfan@yahoo.com \\ ${ }^{+}$Geographical Education Study Program, STKIP Kie Raha, Ternate, 97727, Indonesia \\ E-mail:alwi_lamasinu@yahoo.com
}

\begin{abstract}
Epithermal gold-base metal mineralization at Anggai village, Obi island, Indonesia has been identified through an exploration program by Broken Hill Proprietary Company during 1995 to 1996 . This paper describes a preliminary study on the prospect which focused on its ore and gangue mineralogy, hydrothermal alteration, fluid inclusion microthermometry as well as geochemistry, to elucidate the formation conditions and ore grades. Fresh and altered rocks and mineralization samples were collected from field work to be studied using petrography and ore microscopy, $\mathrm{X}$-ray diffraction analysis, atomic absorption spectrometry, and fluid inclusion microthermometry. The study resulted that host rocks of the mineralization are fine-grained porphyritic basalt and andesite of the Oligocene to Early Miocene Bacan Volcanics. Hydrothermal alteration mineral assemblages include quartz, chlorite, epidote, albite, less biotite, sericite, clay, and pyrite. Mineralization styles are crustiform quartz vein and dissemination, where sulphides clustered and disseminated in closed-space both in quartz gangue and in strongly altered host rocks. Under the microscope, main hypogene ore minerals identified include galena, sphalerite, chalcopyrite, and pyrite which hosts finegrained gold. Fluid inclusion microthermometric study on the vein quartz resulted in homogenization temperature of 220 to $230{ }^{\circ} \mathrm{C}$ and salinity of 2.0 to $2.5 \mathrm{wt}$. \% NaCl equivalent. Chemical analysis of nine selected samples resulted in highest grades of $98 \mathrm{~g} / \mathrm{t} \mathrm{Au}, 275$ $\mathrm{g} / \mathrm{t} \mathrm{Ag,} 0.61 \% \mathrm{Cu}, 48 \% \mathrm{~Pb}$, and $5.35 \% \mathrm{Zn}$.
\end{abstract}

Keywords - obi; epithermal; gold; mineralization; fluid inclusion

\section{INTRODUCTION}

Epithermal gold prospect at Anggai village, Obi island, South Halmahera Province, Indonesia, has been worked by hundreds of artisanal and small-scale gold miners by digging over 200 pits, shafts, and adits, since 1994. The Anggai gold prospect was first explored during 1995 to 1996 by PT. Obi Minerals, a subsidiary company owned by Broken Hill Proprietary (BHP) Minerals Sulawesi Inc. and PT. Aneka Tambang (Indonesian mining company). The company performed 10 holes diamond drilling and gained a range of 6.13 to $26.25 \mathrm{~g} / \mathrm{t}$ gold from depths of 38.0 to $78.6 \mathrm{~m} \mathrm{[1],} \mathrm{[2].}$

In 2007, The Centre Bureau of Geological Resources of Indonesia conducted a preliminary survey in the prospect and reported that the mineralization which hosted in andesitic lava is characterized by sugary and vuggy quartz veins and stockworks that contain sulphides of pyrite, chalcopyrite, and galena. The veins are generally north-south striking with 30 to $50^{\circ}$ dipping to the east, and 2 to $5 \mathrm{~cm}$ thick. Hydrothermal alteration includes silicic, sericitic, and argillic. Chemical analyses resulted in highest grades of $5 \mathrm{~g} / \mathrm{t}$ $\mathrm{Au}$ and $4 \mathrm{~g} / \mathrm{t} \mathrm{Ag}$ in stream sediment, as well as $1 \mathrm{~g} / \mathrm{t} \mathrm{Au}$ and $1 \mathrm{gr} / \mathrm{t} \mathrm{Ag}$ in soil samples [3].

Later, from 2010 to 2011, Ashburton Minerals Ltd., an Australian mining company performed a surface exploration program covering an area of $77 \mathrm{~km}^{2}$ in and around the artisanal goldfield. Some results of the project are briefly described here, as follows. The mineralization style is epithermal Au-Ag vein/breccia. The artisanal workings were closely distributed within an area of about 300 ha, following the strike corridor (about $200 \mathrm{~m}$ wide) of the mineralization which extending southward. Some of the larger veins appeared to be continuous along strike for several hundred meters; the mineralization trend is about 10 $\mathrm{km}$ north-south. At least five separate veins were noted across the strike of the main zone, with individual veins occasionally worked to depths in excess of $50 \mathrm{~m}$. Assay of 15 run-of-mine random samples indicated average grades of 
$\mathrm{Au} 16 \mathrm{~g} / \mathrm{t}$ (from a range of 4.35 to $42.30 \mathrm{~g} / \mathrm{t}$ ), Ag $11 \mathrm{~g} / \mathrm{t}$ (2.30 to $32.30 \mathrm{~g} / \mathrm{t}$ ), $\mathrm{Cu} 0.10 \%$ (0.04 to $0.29 \%), \mathrm{Pb} 0.56 \%$ (0.18 to $1.90 \%$ ), Zn $0.46 \%$ (0.10 to $2.27 \%$ ), and As $149 \mathrm{ppm}$ (43 to $420 \mathrm{ppm}$ ); which beside gold and silver, also indicates significant concentration of base metals and low concentration of arsenic [1], [2].

This paper describes an updated study of the prospect based on recent field and laboratory data, which focused on its ore and gangue mineralogy, hydrothermal alteration, fluid inclusion microthermometry as well as geochemistry, to elucidate the formation conditions and ore grades of the mineralization.

\section{MATERIAL AND METHOD}

\section{A. Geology of Obi Island}

Obi island is one of the northern Molucca islands of Indonesia (Halmahera, Bacan, Obi, Waigeo, and several small islands surrounding Halmahera) which bounded on the south by the strike-slip Sorong fault system; on the west by northern Molucca Sea; on the northeast by south end of the Philippine Trench; and on the east by a northwest-trending member of the Sorong fault system [4], [5] (Fig. 1).

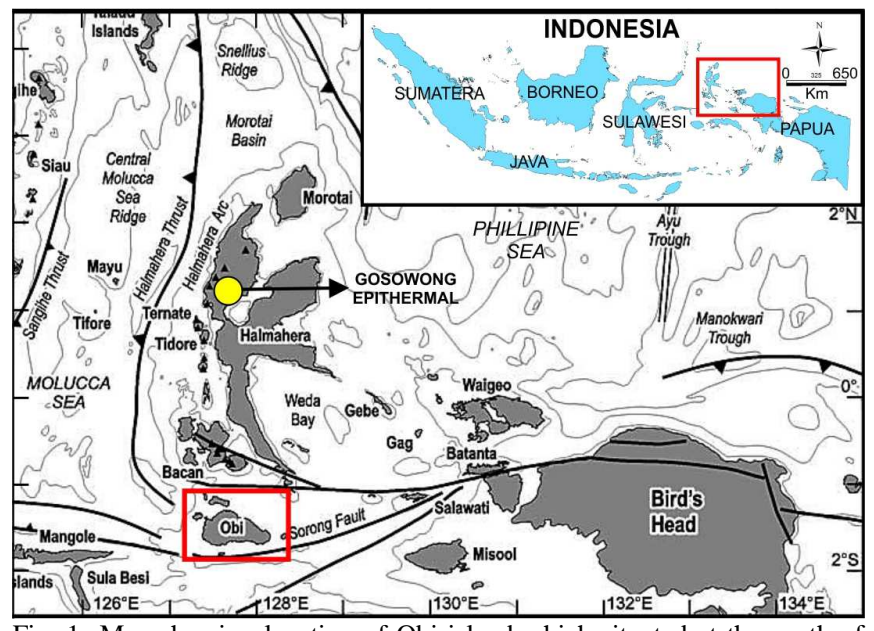

Fig. 1 Map showing location of Obi island which situated at the south of Halmahera island where the Gosowong epithermal lies (modified after [5])

Volcanic rocks in western Halmahera, including Bacan and Obi islands, have an island arc character and are Late Cretaceous to Paleogene in age [6]. Undated hornblende andesite, dacite, tuff, diorite, sheared quartz diorite, and quartz monzonite porphyry indicate magmatic-arc activity at some time, were found in those three islands [4]. High-grade metamorphic continental basement rocks are exposed in Bacan and Obi [6]; both islands have been considered to form one microcontinent, but they may represent different blocks separated by a splay of the Sorong fault system [7]. Since 5 ma, Obi was separated from Halmahera and its surrounding islands by the Sorong fault [5], [8]. These features suggest that regionally Obi island has a similar geological characteristic with Halmahera island where the high-grade gold-silver (27 g/t Au, $38 \mathrm{~g} / \mathrm{t} \mathrm{Ag)} \mathrm{Gosowong}$ epithermal Au-Ag deposit lies [9].

Locally, Obi island is arranged by Pre-Tertiary ultramafic, metamorphic, and metasedimentary rocks; Tertiary volcanosedimentary, clastics and carbonaceous sedimentary, volcanic and intrusive rocks; and Quaternary sediments of reef limestone, terrace and lake deposits, as well as alluvium. One of the Tertiary volcano-sedimentary units is the Oligocene to Early Miocene Bacan Formation, where the Anggai gold prospect (study area) located. This consists of breccia and lava which intercalated by tuffaceous sandstone and claystone. The breccia is composed of andesite, basalt, and red chert fragments; while the lava is greenish grey in color, andesitic, propylitized, and contains calcite and quartz veinlets. This unit is widely distributed in the northern and central parts of the island. Major geological structures in Obi island are north-northwest normal faults which mainly distributed in the north (particularly in the Bacan Formation), and east-west trended anticlines and synclines which mainly distributed in clastic sedimentary units in the south [10].

\section{B. Method}

This study consists of two main stages, field works and laboratory works. The field works were conducted in and around the artisanal goldfield, where fresh and altered rock and mineralization samples were collected randomly and selectively from outcrops as well as from the artisanal workers run of mine. As much as 50 rock and mineralization samples were taken from 15 locations.

The laboratory works consist of petrography, ore microscopy, X-ray diffraction (XRD) analysis, fluid inclusion study, and chemical analysis.

Sample preparations for microscopic studies, i.e., thin sections for petrography and polished sections for ore microscopy, as well as their observations using NIKON transmitted- and reflected light microscope, were performed at Economic Geology Laboratory, Akita University, Japan.

For the XRD analysis, powdered altered rock and mineralization samples were scanned using a RIGAKUMultiflex X-ray diffractometer, with operating conditions as follow: CuKa-radiation, voltage $30 \mathrm{KV}$, and current $16 \mathrm{~mA}$; diffraction patterns were recorded by scanning step of $2^{\circ}$ to $70^{\circ}$ 2-theta, with $0.02^{\circ}$ step size, and 2 seconds per step counting time. All data recorded were further analyzed using PDX-2 program issued by Mineral Data Institute (MDI) combined with Impact Match! version-2 software, to identify mineral species in the samples.

For fluid inclusion study, mineralized vein quartz samples were prepared in $100 \mu \mathrm{m}$ doubly polished wafers to be observed and identified their fluid inclusions under a transmitted light microscope, and then the ice melting and homogenization temperatures were measured using a heating-freezing stage of LINKAM 10035. For determination of salinity, the ice melting temperatures of fluid inclusions resulted from the microthermometry were then converted using the equation of Bodnar [11], [12].

Both the XRD and fluid inclusion microthermometric works were also performed at Economic Geology Laboratory, Akita University, Japan.

For chemical analysis, nine selected mineralization samples were sent to be prepared and analyzed by atomic absorption spectrometry (AAS) method in a commercial research laboratory, PT. Intertek Utama Services, Jakarta, to measure their grades of $\mathrm{Au}, \mathrm{Ag}, \mathrm{Cu}, \mathrm{Pb}$, and $\mathrm{Zn}$. The gold concentration was determined by fire assay with a detection limit of $0.005 \mathrm{ppm}$; whereas for the other four elements, the 
concentrations were determined by acid geochemical digest with detection limits of $\mathrm{Ag} 1 \mathrm{ppm}, \mathrm{Cu} 2 \mathrm{ppm}, \mathrm{Pb} 4$ ppm, and Zn 2 ppm.

\section{RESULTS AND DISCUSSIONS}

Field and microscopic observations revealed that host rocks of the mineralization in the study area are fine-grained porphyritic basalt and andesite. Physical, mineralogical and textural characteristics, as well as their geographic distribution, indicated that the rocks are members of the Bacan Volcanics which Oligocene to Early Miocene in age [10]. Most of the rocks were hydrothermally altered, indicated by light green to green in color which related to the presence of chlorite and epidote that generally observed in the field and hand specimen samples. Detailed alteration study (microscopic and XRD analyses) showed that proximal hydrothermal alteration mineral assemblages include quartz, chlorite, epidote, albite, biotite, sericite, clay, and pyrite. Under the microscope, it was observed that in samples of strongly altered host rock, the alteration was generally developed in three stages: (1) coarse-grained quartz and less chalcedony in banded texture, (2) finegrained quartz \pm clay, sericite, chlorite, epidote, less albite and secondary biotite, and opaque, and (3) opaque in veins and disseminated (Fig. 2). The opaques were further identified by XRD, dominated by pyrite. This figures suggested that in general, the distal hydrothermal alteration is the propylitic type, which indicated by the dominant appearance of chlorite and epidote, whereas in the more proximal, silicic and argillic (indicated by the dominance of quartz and clay minerals) are the main alteration types.

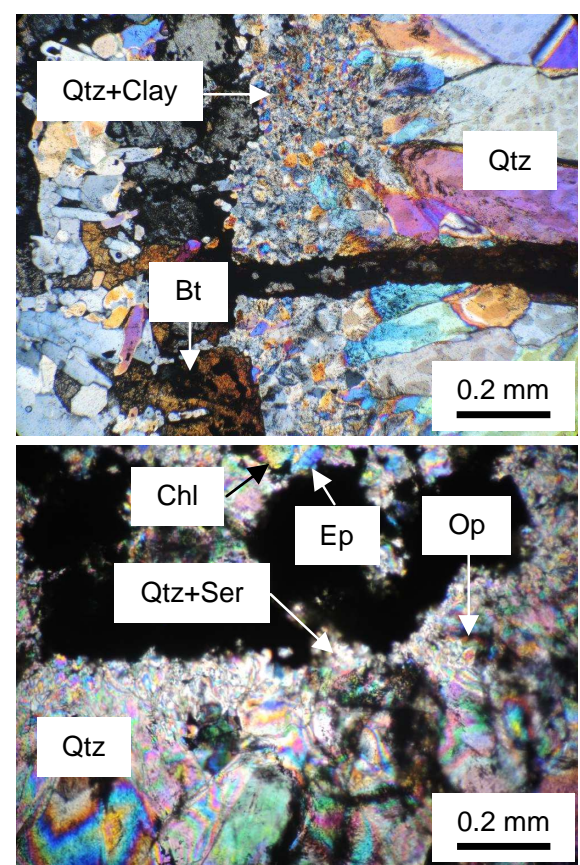

Fig. 2 Photomicrographs of two strongly altered host rock samples showing mineral assemblages discussed in the text: quartz (Qtz), clay, secondary biotite (Bt), chlorite (Chl), epidote (Ep), sericite (Ser), and opaque (Op)

In the epithermal environment, some hydrothermal alteration minerals have a sensitive temperature that can be used to estimate their formation temperature and $\mathrm{pH}$ of the responsible hydrothermal fluid. As described, chlorite, epidote, biotite, and sericite were recognized in this study (Fig. 2). These are the sensitive temperature hydrothermal alteration minerals. Studies of hydrothermal minerals stability in epithermal environment suggested that chlorite formed at temperature range of about 200 to $300^{\circ} \mathrm{C}$, epidote in about 200 to $320^{\circ} \mathrm{C}$, biotite about 260 to $300^{\circ} \mathrm{C}$, and sericite in temperature above $220^{\circ} \mathrm{C}$; all formed from a nearneutral to slightly acid pH fluid [13], [14], [15], [16]. Therefore, by combining the formation temperature ranges of the four minerals, it can be interpreted that based on its hydrothermal alteration characteristics, the mineralization at Anggai prospect was formed in the temperature range of about 200 to $320^{\circ} \mathrm{C}$, from a near-neutral to the slightly acid $\mathrm{pH}$ fluid.

The mineralization styles are crustiform quartz vein and dissemination, where sulphide ore minerals clustered and disseminated in closed-space both in quartz gangue and in strongly altered host rocks. Beside quartz, crystals of amethyst were also observed as gangue. In hand specimens, the quartz veins ( 1 to $8 \mathrm{~cm}$ thick) and veinlets $(0.1$ to $0.9 \mathrm{~cm})$ were generally characterized by crustiform banded, crystalline (mostly hexagonal, maximum $1.5 \mathrm{~cm}$ to finegrained saccharoidal quartz), comb, and vuggy textures. Fine to coarse grains pyrite, chalcopyrite, galena, and sphalerite were the main sulphides identified in hand specimen samples (e.g., Fig. 3). Crystals of galena and sphalerite were observed occurred in disseminated coarse grains, $1.3 \mathrm{~cm}$ for galena and nearly $1 \mathrm{~cm}$ for sphalerite; in one sample, a sulphide band of galena also found, which indicates the dominant occurrence of base metal in the mineralization.

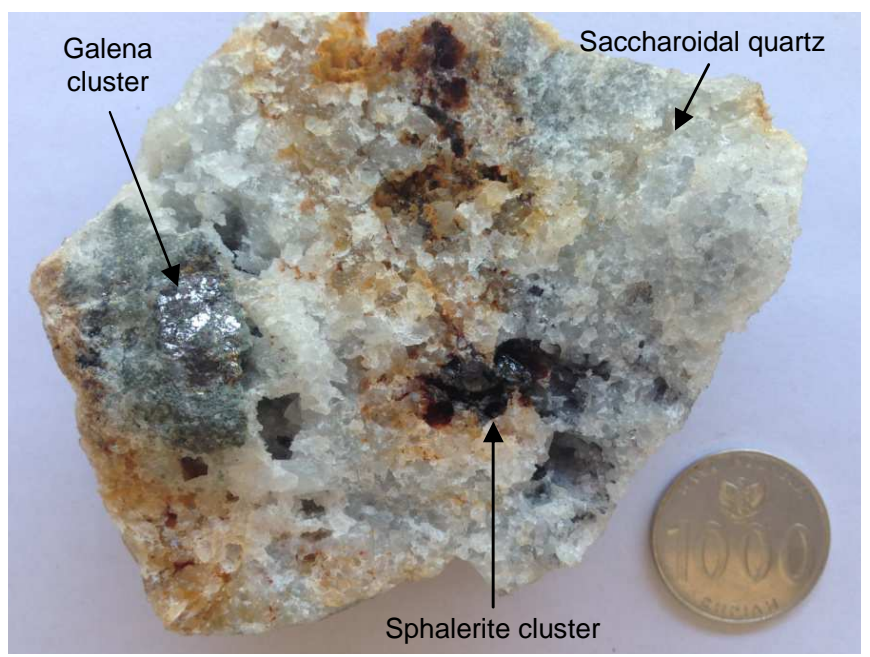

Fig. 3 Hand specimen sample of highly mineralized saccharoidal vuggy quartz from crustiform vein (sample code: ST.12.B), showing clusters of galena and sphalerite

Under the microscope, hypogene ore minerals identified include galena, sphalerite, chalcopyrite, pyrite, and less tennantite-tetrahedrite (Fig. 4.A and 4.B). Paragenetically, sphalerite, and galena mostly occurred as early stage minerals, where sphalerite precipitated earlier than galena, as indicated by texture shown in Fig. 4.B, where finer galena crystals distributed on bigger sphalerite. Chalcopyrite and pyrite were the later minerals, as shown in Fig. 4.A and 4.B, and tennantite-tetrahedrite were the latest. Fine-grained electrum $(20 \mu \mathrm{m})$ was observed as inclusion in euhedral 
pyrite crystal (Fig. 4.C), from a highly mineralized quartz vein sample (sample in Fig. 3). Supergene minerals covellite and goethite were also identified in polished sections, where covellite generally distributed around the fringe of chalcopyrite, and some totally replaced chalcopyrite, while goethite mostly replaced pyrite.
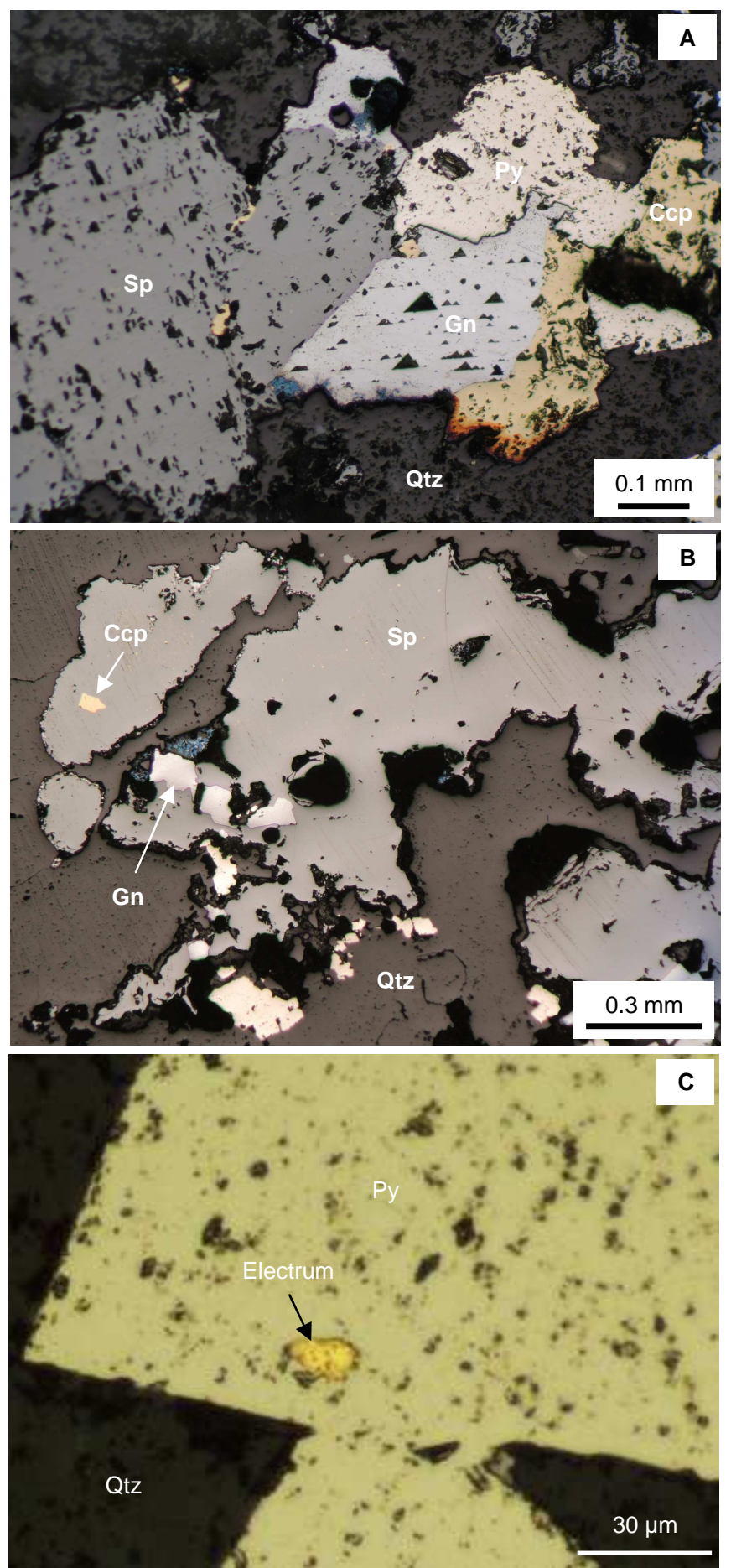

Fig. 4 Polished section photomicrographs are showing the existing ore mineral assemblages in selected mineralization samples. Fig. A, B: sphalerite (Sp), galena (Gn), chalcopyrite (Ccp), and pyrite (Py) distributed in quartz (Qtz). Fig. C: fine-grained electrum in pyrite (sample ST.12.B)

Nine selected mineralization samples were assayed using AAS method to measure their $\mathrm{Au}, \mathrm{Ag}, \mathrm{Cu}, \mathrm{Pb}$ and $\mathrm{Zn}$ grades. The result is shown in Table I. Generally, the range of ore grades are 1.36 to $98 \mathrm{~g} / \mathrm{t} \mathrm{Au}, 2$ to $275 \mathrm{~g} / \mathrm{t} \mathrm{Ag}, 0.02$ to $0.61 \%$ $\mathrm{Cu}, 0.02$ to $48 \% \mathrm{~Pb}$, and 0.06 to $5.35 \% \mathrm{Zn}$. The highest grade of each element is as follows: $98 \mathrm{~g} / \mathrm{t} \mathrm{Au}, 275 \mathrm{~g} / \mathrm{t} \mathrm{Ag}$, $0.61 \% \mathrm{Cu}, 48 \% \mathrm{~Pb}$, and $5.35 \% \mathrm{Zn}$.

TABLE I

ORE GRADES MEASURED BY AAS METHOD

\begin{tabular}{|l|r|r|r|r|r|}
\hline $\begin{array}{l}\text { Sample } \\
\text { code }\end{array}$ & \multicolumn{1}{c|}{$\begin{array}{c}\text { Au } \\
(\mathbf{p p m})\end{array}$} & $\begin{array}{c}\mathbf{A g} \\
(\mathbf{p p m})\end{array}$ & $\begin{array}{c}\text { Cu } \\
(\mathbf{\%})\end{array}$ & $\begin{array}{c}\text { Pb } \\
(\mathbf{\%})\end{array}$ & $\begin{array}{c}\text { Zn } \\
(\boldsymbol{\%})\end{array}$ \\
\hline ST.04.B & 1.36 & 2 & 0.03 & 0.02 & 0.06 \\
\hline ST.07.B & 30.80 & 13 & 0.16 & 2.12 & 5.35 \\
\hline ST.08.B & 2.62 & 17 & 0.61 & 0.34 & 1.33 \\
\hline ST.09.B & 13.60 & 275 & 0.21 & 48.00 & 0.16 \\
\hline ST.10.B & 2.59 & 7 & 0.16 & 0.87 & 1.04 \\
\hline ST.10.P & 4.62 & 4 & 0.06 & 0.14 & 0.52 \\
\hline ST.11.B & 5.72 & 10 & 0.11 & 0.37 & 0.61 \\
\hline ST.12.B & 98.00 & 33 & 0.54 & 1.33 & 1.40 \\
\hline ST.15.B & 3.10 & 3 & 0.02 & 0.03 & 0.06 \\
\hline
\end{tabular}

It shows in Table 1 that sample with code ST.07.B is rich

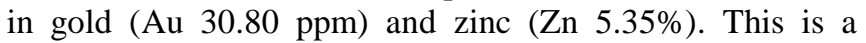
quartz vein sample hosted in the strongly greenish altered host rock. In hand specimen, the vein showed vuggy texture with general vug diameter of 0.1 to $1.6 \mathrm{~cm}$ which filled by fine hexagonal comb-crystalline quartz; clusters of oxidized sulphide were also observed in the vein (Fig. 5). Finegrained sphalerite, galena, pyrite, and chalcopyrite were recognized scarcely disseminated in the hand specimen sample. Polished section photomicrograph of this sample is shown in Fig. 4.B where coarse-grained sphalerite showed as dominant early stage mineral.

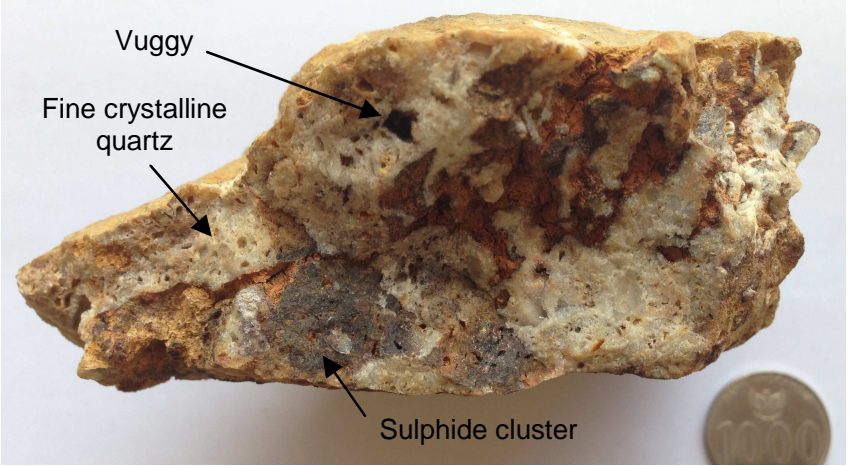

Fig. 5 Hand specimen sample of quartz vein which according to AAS assay, rich in zinc and gold (ST.07.B)

The sample ST.09.B is rich in the lead $(\mathrm{Pb} \mathrm{48 \% )}$ and silver (Ag $275 \mathrm{ppm})$, Table 1. This is also a quartz vein (1.2 $\mathrm{cm})$ sample that hosted in greenish-grey altered host rock (Fig. 6). The vein composed by comb quartz, crystalline, hexagonal, and vuggy $(0.2$ to $0.7 \mathrm{~cm})$ filled by comb quartz crystals; fine-grained galena scarcely disseminated in the vein and altered host rock. Quartz veinlets $(0.1$ to $0.3 \mathrm{~cm})$ were also observed in the host rock. Polished section photomicrograph of this sample is shown in Fig. 4.A where coarse-grained galena together with sphalerite occurred as early stage minerals. Silver mineral was not recognized under the microscope, probably because of the small size. 


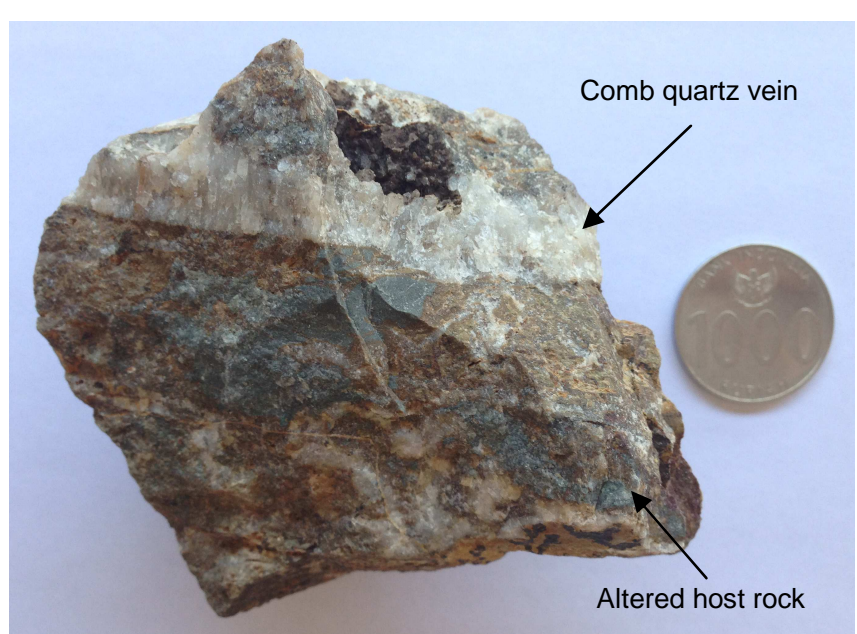

Fig. 6 Hand specimen sample showing quartz vein hosted in the altered host rock, which according to AAS assay, rich in lead and silver (ST.09.B)

Sample with code ST.12.B that contains the highest gold grade is a strong silicified quartz vein sample which had an intensive vuggy $(0.1$ to $0.3 \mathrm{~cm})$ and saccharoidal quartz texture. Medium to coarse-grained sulphides was clustered in the vein, with a dimension of each cluster is 1.7 to $2.0 \mathrm{~cm}$. Galena, chalcopyrite, sphalerite, and pyrite were disseminated in very closed-space in each cluster. Single crystals of galena were up to $5 \mathrm{~mm}$, and sphalerite was up to $2 \mathrm{~mm}$. Hand specimen and microscopic photographs of this sample are shown in Fig. 3 and Fig. 4.C, respectively.

The fluid inclusion microthermometric study was conducted in quartz of mineralized veins. Under the microscope, the size of fluid inclusions generally ranges from $<5$ to $30 \mu \mathrm{m}$, vary in shape, mostly angular, elongated, and prismatic. At room temperature, all fluid inclusions showed two-phase liquid-vapor (liquid rich) with a range of $\mathrm{V} /(\mathrm{V}+\mathrm{L}$ ) 10 to $50 \%$ (Fig. 7). The inclusions spread parallel, and some are defining the quartz crystal fringes as a cluster of inclusions and were interpreted as primary inclusions; less was found trapped along microfractures, which classified as secondary inclusions, according to the criteria of [17], [18]. Homogenization- and ice melting temperature were only measured on the primary inclusions.
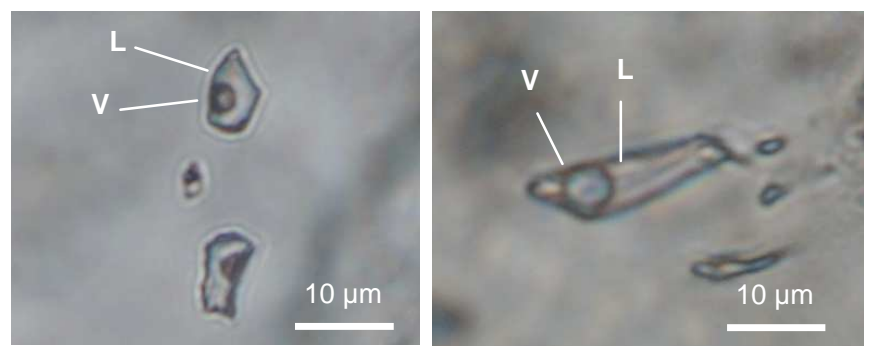

Fig. 7 Photomicrographs of primary two-phase liquid-vapor (liquid-rich) fluid inclusions in vein quartz (sample code: ST.12.B). L: liquid, V: vapor

Histograms of fluid inclusion microthermometric results are shown in Fig. 8. As described in the method, the salinity values were determined by converting ice melting temperatures using the equation of Bodnar [11], [12]. Based on the peaks of the histograms, it is estimated that trapping or formation temperature of the mineralization in the study area is 220 to $230^{\circ} \mathrm{C}$, while salinity of the responsible hydrothermal fluid is 2.0 to $2.5 \mathrm{wt} . \% \mathrm{NaCl}$ equivalent. These temperature and salinity values are more or less consistent with those interpreted by hydrothermal alteration study, described previously. The trend of homogenization temperature $v s$. salinity plot of the highest gold grade sample (ST.12.B), which generally parallel to salinity axis (Fig. 9), indicated that the mineralization precipitated from a hydrothermal fluid that isothermally mixed with other contrasted salinity fluid, and not related to boiling [19]. The estimated formation temperature was then used to infer formation- depth, and pressure of the mineralization using the boiling point curve and P-V-T data of Haas [20]. Since the curve was constructed using P-V-T data of boiling condition, while there are no indications of the boiling mechanism responsible for the precipitation, thus the formation depth estimated in this study is minimum depth. By plotting the formation temperature to the boiling point curve, the estimated minimum depth of the formation is 250 to $300 \mathrm{~m}$ below the paleo-water table, which corresponds to 23 to 28 bar hydrostatic pressure [20].

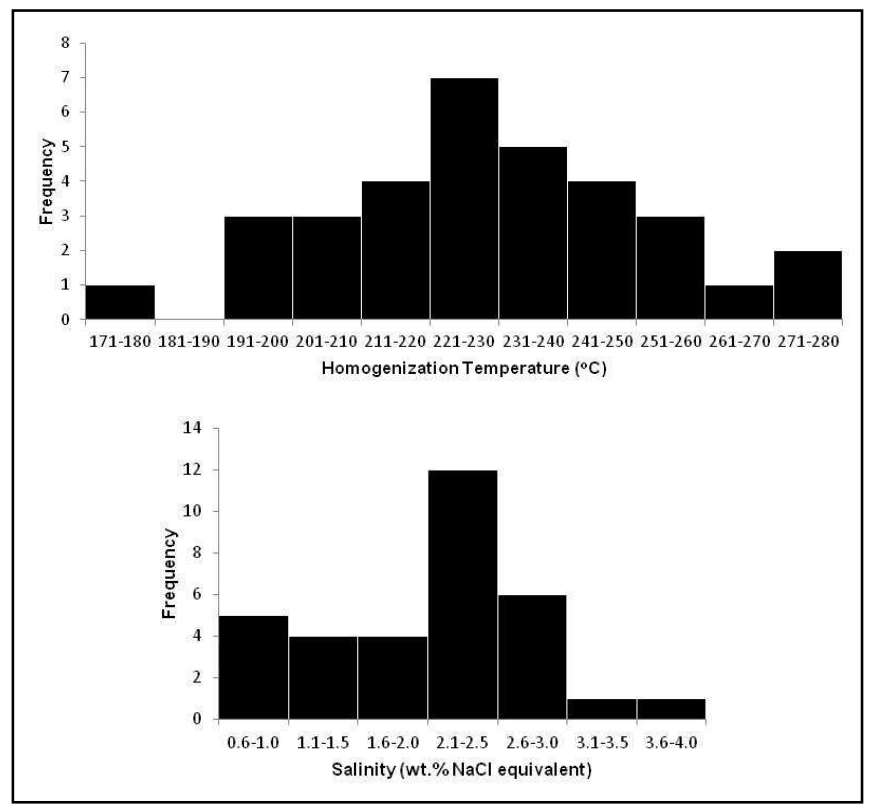

Fig. 8 Histograms of homogenization temperature and salinity determined from fluid inclusion microthermometry (sample ST.12.B, n=33)

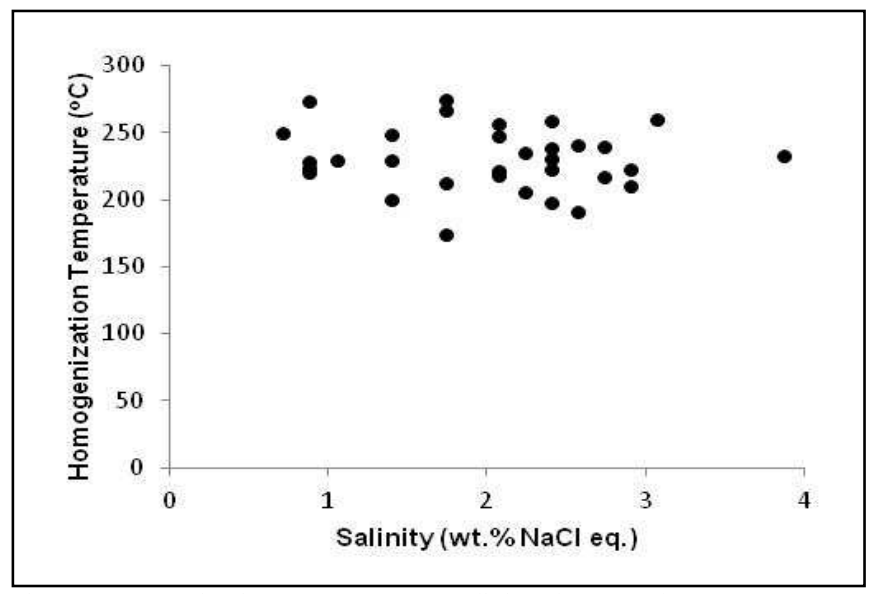

Fig. 9 Homogenization temperature $v s$ salinity plot (sample ST.12.B, n=33) 


\section{CONCLUSIONS}

Several conclusions can be defined from this study, as follows. Host rocks of the mineralization are members of the Oligocene to Early Miocene andesitic-basaltic Bacan Volcanics, which in the study area they are generally hydrothermally altered. Hydrothermal alteration mineral assemblages include quartz, chlorite, epidote, albite, biotite, sericite, clay, and pyrite. The hydrothermal alteration was zoned from distal propylitic (mainly characterized by chlorite and epidote) to proximal silicic and argillic (quartz and clay). Study of sensitive temperature hydrothermal alteration minerals indicated that the mineralization at Anggai prospect was formed in the temperature range of about 200 to $320^{\circ} \mathrm{C}$, from a near-neutral to the slightly acid $\mathrm{pH}$ fluid.

Mineralization styles are quartz vein and disseminated with identified hypogene ore minerals of galena, sphalerite, chalcopyrite, pyrite, less tennantite and tetrahedrite, and gold (electrum). Covellite and goethite were also identified as supergene minerals. Range of ore grades are: 1.36 to $98 \mathrm{~g} / \mathrm{t}$ $\mathrm{Au}, 2$ to $275 \mathrm{~g} / \mathrm{t} \mathrm{Ag}, 0.02$ to $0.61 \% \mathrm{Cu}, 0.02$ to $48 \% \mathrm{~Pb}$, and 0.06 to $5.35 \% \mathrm{Zn}$. Based on the relationships between the ore mineral assemblages and their grades, it is concluded that the mineralization in the prospect is gold, less silver, and base metals.

Based on fluid inclusion study, the mineralization in the study area is inferred to be formed in temperature range of 220 to $230^{\circ} \mathrm{C}$, pressure of 23 to 28 bar, within a depth range of 250 to $300 \mathrm{~m}$ below paleo-water table, precipitated from hydrothermal fluid that isothermally mixed with contrasted salinity fluid (salinity range of 2.0 to 2.5 wt.\% $\mathrm{NaCl}$ equivalent), and not related to boiling mechanism.

The whole hydrothermal alteration characteristics, ore and gangue mineral assemblages, mineralization styles and their textural properties, fluid inclusion signatures particularly the two-phase liquid-vapor (liquid rich) dominant inclusions in vein quartz, as well as the physicochemical conditions of the formation (temperature, pressure, depth, precipitation mechanism, and salinity of responsible hydrothermal fluid) indicated that the gold-base metal mineralization in the study area is epithermal low sulphidation.

\section{ACKNOWLEDGMENT}

This study was financially supported by JICA and Hasanuddin University Engineering Faculty Development Project, through 2015 Short-term Visiting Research Program granted to the first author. The authors deeply appreciate Prof. Akira Imai, Prof. Yasushi Watanabe, Dr. Ryohei Takahashi and all members of the Economic Geology Laboratory for the constructive suggestions, discussions and help during the works at Akita University.

\section{REFERENCES}

[1] T. Dukovcic, "Obi gold project, Indonesia," Ashburton Minerals Ltd. Published Annual Report, 2010. [Online]. Available: http://www.ashburton-minerals.com.au.

[2] T. Dukovcic, "Obi potential confirmed by high grade historical drilling," Ashburton Minerals Ltd. Published Annual Report, 2011. [Online]. Available: http://www.ashburton-minerals.com.au.

[3] S. Sudarya, "Metal minerals inventory in South Halmahera Regency and Tidore Island, North Molucca (in Indonesian)," in Proc. Field and Nonfield Activity Results, 2007, Centre of Geological Resources, Bandung, Indonesia, $9 \mathrm{p}$.

[4] W. Hamilton, "Tectonics of the Indonesian region," US. Geological Survey Professional Paper, vol. 1078, 345 pp, 1979.

[5] R. Hall, "Cenozoic geological and plate tectonic evolution of SE Asia and the SW Pacific: computer-based reconstructions, model and animations," Journal of Asian Earth Sciences, vol. 20, pp. 353-431, 2002.

[6] R. Hall, G. Nichols, P. Ballantyne, T. Charlton and J. Ali, "The character and significance of basement rocks of the southern Molucca Sea region," Journal of Southeast Asian Earth Sciences, vol. 6, pp. 249-258, 1991.

[7] P. Z. Vroon, M. J. Van Bergen and E. J. Forde, "Pb and Nd isotope constraints on the provenance of tectonically dispersed continental fragments in east Indonesia," In R. Hall and D. Blundell, Eds., Tectonic evolution of Southeast Asia, Geological Society Special Publication, no. 106, pp. 445-453, 1996.

[8] R. Hall, "Australia-SE Asia collision: plate tectonics and crustal flow," In R. Hall, M. A. Cottam and M. E. J. Wilson, Eds., The SE Asian gateaway: history and tectonics of the Australia-Asia collision, Geological Society Special Publication, no. 355, pp. 75-109, 2011.

[9] J. B. Gemmell, "Hydrothermal alteration associated with the Gosowong epithermal Au-Ag deposit, Halmahera, Indonesia: mineralogy, geochemistry, and exploration implications," Economic Geology, vol. 102, pp. 893-922, 2007.

[10] D. Sudana, A. Yasin and K. Sutisna, "Geological map of the Obi sheet, Maluku,". Geological Research and Development Centre, Bandung, Indonesia, 1994

[11] R. J. Bodnar, "Revised equation and table for determining the freezing point depression of $\mathrm{H}_{2} \mathrm{O}-\mathrm{NaCl}$ solutions," Scientific Comment, Geochimica et Cosmochimica Acta, vol. 57, pp. 683-684, 1993.

[12] R. J. Bodnar and M. O. Vityk, "Interpretation of microthermometric data for $\mathrm{H}_{2} \mathrm{O}-\mathrm{NaCl}$ fluid inclusions," In B. De Vivo and M. L. Frezzotti, Eds., Fluid Inclusions in Minerals, Methods and Applications, Virginia Tech, Blacksburg, VA, pp. 117-130, 1994.

[13] A. G. Reyes, "Petrology of Philippine geothermal systems and the application of alteration mineralogy to their assessment," Journal of Volcanology and Geothermal Research, vol. 43, pp. 279-309, 1990.

[14] N. C. White and J. W. Hedenquist, "Epithermal environments and styles of mineralization: variations and their causes, and guidelines for exploration," Journal of Geochemical Exploration, vol. 36, pp. 445-474, 1990.

[15] J. W. Hedenquist, E. Izawa, A. Arribas and N. C. White, "Epithermal gold deposits: styles, characteristics, and exploration," Resource Geology Special Publication, No. 1, Tokyo, 1996.

[16] J. W. Hedenquist, A. Arribas R. and E. Gonzalez-Urien, "Exploration for epithermal gold deposits," Reviews in Economic Geology, vol. 13 p. 245-277, 2000.

[17] E. Roedder, "Fluid inclusions," In P. H. Ribbe, Ed., Reviews in Mineralogy, Mineralogical Society of America, BookCrafters, Inc., Chelsea, Michigan, vol. 12, 646 p., 1984.

[18] R. J. Bodnar, T. J. Reynolds and C. A. Kuehn, "Fluid-inclusion systematic in epithermal systems," In B. R. Berger and P. M. Bethke, Eds., Geology and geochemistry of epithermal systems, Reviews in Economic Geology, vol. 2, pp. 73-97, 1985.

[19] J. J. Wilkinson, "Fluid inclusions in hydrothermal ore deposits," Lithos, vol. 55, pp. 229-272, 2001.

[20] J. L. Haas, "The effect of salinity on the maximum thermal gradient of a hydrothermal system at hydrostatic pressure," Economic Geology, vol. 66, pp. 940-946, 1971. 